487 pp. An abstract of the paper by A. Horth, which follows this report, illustrates the coverage given in typical abstracts.

J. W. KeR

\title{
Forest Inventory Developments in British Columbia
}

The initial objective of the Forest Surveys and Inventory Division of the B.C. Forest Service was to obtain a reasonably accurate inventory of the forest resources of the Province of British Columbia. Such an extensive survey was completed in 1957 and the results were published in the report, "Continuous Forest Inventory of British Columbia." The current objective of the Division is to maintain this inventory and at the same time to secure answers of sufficient accuracy to permit management planning of Crown units.

In a province whose total area is in excess of 234 million acres, or which over 90 per cent is administered by the Crown, such an objective is no small task. Nearly 60 per cent of the total area is in the form of forest land.

The basic data from the provincial inventory report make is possible to proceed with Crown unit surveys. Such surveys are designed to provide suitable information for over-all forest-management planning in a relatively large forest unit. These areas vary in size generally from 100,000 acres to $3,000,000$ acres, and 73 such units have already been established. This type of survey provides forest cover maps, area estimates, and estimates of standing timber volumes to a specified degree of accuracy and net forest growth. This information is suitable for the construction of a working plan designating a preliminary allowable annual cut for the unit.

To meet the intensive needs of Crown unit management planning, efficient and accurate field survey methods and office procedures are employed. Helicopters are used extensively for low-level observation in forest classification and for the transport of field crews in forest sampling. All survey work is recorded on aerial photographs at the approximate scale of one inch equals one-quarter mile.

Every consideration is given to new survey methods that appear to be of value. The application of photo-mensuration techniques for estimating timber volumes from aerial photographs has warranted the use of the standvolume method as a means of obtaining accurate and inexpensive standvolume estimates.

Another development is low-level stereo-photography. A recent paper describes a method of obtaining flying height above ground from the photomeasured base length of two cameras, mounted one at each end of a fifteenfoot boom suspended longitudinally beneath a helicopter. Results have been favorable. Further study of these stereo-photos in measuring tree heights, ground area, tree counts, and species will determine the worth of this technique as an aid in both forest classification and volume sampling.

New growth estimates have recently been compiled for the province. An intensive program based on permanent plots that will consider all aspects of growth and yield is now under way. 
Excellent progress has been made in analyzing the measurements of over 27,000 felled trees for volume-table and loss-factor purposes. A new publication of these data covering all the commercial species in the province will be issued in 1961 .

An I.B.M. 650 computer and other electronic data-processing equipment is used to process all data. Such efficient equipment will always be required to process the answers for Crown management planning purposes.

A. HorTh, Forest Surveys and Inventory Division, British Columbia Forest Service, Victoria, B.C., Canada.

\section{REVIEWS}

Reviews of books, reports, papers and other publications should be sent to $J$. Walter Giles, Book Review Co-ordinator, Lands Branch, Department of Lands and Forests, Parliament Buildings, Toronto 5, Ont. Please mention that you saw the review in The Forestry Chronicle when purchasing books from publishers.

\section{Current Publications}

GeNERAL

Lake States Forest Experiment Station 1961. Outdoor Recreation in the Upper Great Lakes Area. Sta. Pap 89 L.S.F.E.S. St. Paul, Minn. 104pp.

Olsen, L. P. 1961. Publications of the Lake States Forest Experiment Station 1956-1960. Sta. Pap. 39, L.S.F.E.S. 67 pp.

Sisam, J. W. B. 1961. Forestry Education at Toronto. Univ. Toronto Press, $116 \mathrm{pp}$.

Stone, R. N. 1961. Current timber growth estimates for the Lake States. Tech. Note 604. L.S.F.E.S. St. Paul. 2 pp.

Stone, R. N. and H. W. Thorne. 1961. Wisconsin's Forest Resources. Sta. Pap. 90. L.S.F.E.S. 52 pp.

U.S. Forest Service, 1961. Forestry and forest industry in the U.S.S.R. Report of a technical study group. U.S.F.S., Washington. $92 \mathrm{pp}$.

\section{MANAGEMENT}

Bean, J. L. and W. E. Waters. 1961. Spruce Budworm in the eastern United States. Forest pest leaflet 58. U.S.D.A. Washington. 8 pp.

Cox, P. 1961. A test of variable plot cruising in mixed stands on Latour State Forest. For. Note 5. California Div. For. 6 pp.

Cramer, O. P. 1961. Adjustment of relative humidity and temperature for differences in elevation. Res. Pap, 43. P.N.W.F.R.E.S. 21 pp.

Hastings, A. R. and M. Beroza, 1961. Screening tests of chemical deterrents. Sta. Pap. 156. N.E.F.E.S. 13 pp.

Hawboldt, L. S. and S. N. Kostjukovits, 1961. Site quality normal yield tables for softwoods. Part I. Forest Regulation for Nova Scotia. Bul. No. 20. Nova Scotia Dept. L. \& F. Halifax.

-1961. Stand Description Cruising. Part II. Forest regulation for Nova Scotia. Bul. No. 21. 7 pp. 